\title{
Parasitic chytrids: their effects on phytoplankton communities and food-web dynamics
}

\author{
Maiko Kagami · Arnout de Bruin · \\ Bas W. Ibelings · Ellen Van Donk
}

(C) Springer Science+Business Media B.V. 2007

\begin{abstract}
Many phytoplankton species are susceptible to fungal parasitism. Parasitic fungi of phytoplankton mainly belong to the Chytridiomycetes (chytrids). Here, we discuss the progression made in the study of chytrids that parasitize phytoplankton species. Specific fluorescent stains aid in the identification of chytrids in the field. The established culturing methods and the advances in molecular science offer good potential to gain a better insight into the mechanisms of epidemic development of chytrids and coevolution between chytrids and their algal hosts. Chytrids are often considered to be highly host-specific parasites, but the extent of host specificity has not been fully investigated. Chytrids may prefer larger host cells, since they would gain more resources, but whether hosts are really
\end{abstract}

Guest editors: M. Albay, J. Padisák \& L. Naselli-Flores Morphological plasticity of phytoplankton under different environmental constraints.

\footnotetext{
M. Kagami · A. de Bruin · B. W. Ibelings ·

E. Van Donk

Department of Food Web Studies, Center for Limnology, Netherlands Institute of Ecology

(NIOO-KNAW), Rijksstraatweg 6, 3631AC

Nieuwersluis, The Netherlands

Present Address:

M. Kagami ( $\square)$

Department of Environmental Science, Faculty of

Science, Toho University, Miyama 2-2-1, Funabashi

274-8510, Japan

e-mail: Kagami@env.sci.toho-u.ac.jp
}

selected on the basis of size is not clear. The dynamics of chytrids epidemics in a number of studies were partly explained by environmental factors such as light, temperature, nutrients, $\mathrm{pH}$, turbulence and zooplankton grazing. No generalization was made about the epidemic conditions; some state unfavorable conditions for the host growth support epidemic development, while others report epidemics even under optimal growth conditions for the host. Phytoplankton is not defenseless, and several mechanisms have been suggested, such as a hypersensitivity response, chemical defense, maintaining a high genetic diversity and multitrophic indirect defenses. Chytrids may also play an important role in food webs, because zoospores of chytrids have been found to be a good food source for zooplankton.

Keywords Host-parasite interactions . Epidemics · Host specificity · Cell size · Defense $\cdot$ Food webs

\section{Introduction}

Fungal parasitism on phytoplankton is still a neglected subject, although progress has been made during the last decades. We are not the first to make this observation (see e.g. Cook, 1963; Masters, 1976; Reynolds, 1984; Van Donk \& Bruning, 1992). This neglect is partly a consequence of the nature of 
parasitic infections: they often escape the notice of non-specialists, and their epidemic development is often unpredictable, which has made it difficult to study chytrids in relation to other factors affecting phytoplankton populations (Reynolds, 1984; Van Donk, 1989). On the other hand, Bruning (1991c) emphasized that fungal parasitism, unlike grazing or sedimentation, is a loss factor which is directly perceptible. This should facilitate field investigations, especially when specific fluorescent stains - which avoid confusion with other attached non-parasitic organisms-are used (Müller \& Sengbusch, 1983). In addition, established culture systems make experimental work possible, which should help to unravel the mechanisms underlying epidemic development.

The work devoted to taxonomy and occurrence of algal parasites by a relatively small number of researchers in the 1940s, 1950s and 1960s (Ingold, 1940, 1941, 1944; Canter, 1946, 1947a, b, c; Canter \& Lund, 1948; Canter, 1949a, b, c, 1950a, b, c, 1951; Canter \& Lund, 1951; Canter, 1953; Canter \& Lund, 1953; Canter, 1954, 1960, 1961, 1966, 1967, 1968, 1969; Canter \& Lund, 1969) may give the impression that "fungal parasites have been studied for a considerable period of time, and indeed much has been learned about the occurrence of chytrids from these works.

Molecular science has progressed a great deal since the 1960s. Molecular studies now firmly place the Chytridiomycetes within the fungal kingdom (Bowman et al., 1992; Tehler et al., 2000). The progress of molecular techniques and the well established cultural system offer us new possibilities to study chytrid dynamics with a higher resolution than before, and to challenge some research questions that have not yet been solved. Intriguing questions include coevolution between phytoplankton and chytrids, or the role of chytrids in the food-web dynamics. In this paper, we give a general description of chytrids with relatively detailed attention to methods used in the study of chytrids, and a special emphasis on more recent developments in this research. This paper complements and builds on information summarized in an earlier review (Ibelings et al., 2004). We refer the taxonomy and life cycle of chytrids to Ibelings et al. (2004), and to Chytrid Fungi Online: (http://www.bama.ua.edu/ nsfpeet) where recent updates of chytrids taxonomy can be found.

\section{Visualization of chytrids}

Chytrids may remain undetected by non-specialists or are often confused with other organisms, for instance flagellates such as Bicosoeca (Canter Lund \& Lund, 1995). These flagellate protozoans feed on bacteria, and do not harm the algae to which they are attached. Special dyes and key morphological differences are helpful to identify and distinguish chytrids from other organisms with a chytrid-like appearance. Zoospores of chytrids have a single straight flagellum (Canter, 1967), and a spherical body (2-3 $\mu \mathrm{m}$ in diameter) containing a conspicuous oil globule and a single nucleus. This oil globule is already quite visible (at a magnification of $400 \times$ ), but can also be stained with Nile Red (Kudoh, 1990). The nucleus can be stained with 4',6-diamidino-2-phenilindole (DAPI) or Syber green (Noble \& Fuhrman, 1998). Before staining, the samples should be fixed with glutaraldehyde ( $1 \%$ final concentration). Therefore, $1-\mathrm{mL}$ samples are put into Utermohl counting chambers, to which $100 \mu \mathrm{g} \mathrm{L}^{-1}$ of Nile Red and $50 \mu \mathrm{g} \mathrm{L}^{-1}$ of 4',6-diamidino-2-phenilindole (DAPI) were added (both in final concentrations). The samples are then incubated for $30 \mathrm{~min}$ in the dark at room temperature. Nile Red stains the oil globule of the zoospores, emitting a characteristic orange fluorescence under green excitation $(525 \mathrm{~nm})$. DAPI stains the nucleus emitting blue fluorescence under ultraviolet (UV) excitation (365 nm).

Chytrids in the different stages of their life cycle (attached zoospores, sporangia and empty sporangia) can be stained with CalcoFluor White (Müller \& Sengbusch, 1983). Three drops of $10 \% \mathrm{KOH}$ solution and three drops of $0.1 \%$ CalcoFluor White solution were added to 1-mL samples in Utermohl counting chambers, after which the samples were incubated for $10 \mathrm{~min}$. CalcoFluor White binds to chitin, a cell wall component of chytrids. The sample should be fresh or fixed with gultaraldehyde, but not with Lugol's solution. A more detailed protocol can be obtained at Mycology online (http://www.mycology.adelaide.edu.au/). 


\section{Culturing chytrids}

With some effort parasitic chytrids can be isolated from lakes using elongated micropipettes and an inverted microscope and maintained in the laboratory. The isolated infected host cells are transferred into fresh uninfected host cultures, which then are kept under favorable environmental conditions for growth of the chytrids (relatively high light and temperature, see Bruning, 1991b). This way, parasite cultures are obtained as a nonaxenic batch culture (Canter \& Jaworski, 1978; Bruning, 1991d). Freshly isolated infected host cells can also be used for the short-term experiments without maintaining in the laboratory (Van Donk \& Ringelberg, 1983; Kagami \& Urabe, 2002).

The chytrid, Zygorhizidium planktonicum can be maintained on its host algae, Asterionella formosa, in non-axenic batch cultures, using the following procedure: 150-mL 1-week-old uninfected $A$. formosa host culture can be infected with 5 to $10-\mathrm{mL}$ of a 1 -week-old $Z$. planktonicum culture. The $A$. formosa host cultures can be maintained on a modified Chu-10 medium (Stein, 1973) at $40 \mu \mathrm{mol}$ quanta $\mathrm{m}^{-2} \mathrm{~s}^{-1}$ with a $14: 10 \mathrm{~h}$ light :dark cycle and a temperature of $18^{\circ} \mathrm{C}$. Culture conditions should be modified according to the particular growth rates of chytrids and host algae (Bruning, 1991b).

Highly infected host cultures are characterized by multiple infected cells and free-swimming zoospores in the medium. Filtering of infected host cultures, using filters with a specific pore size (e.g. $5 \mu \mathrm{m}$ mesh) makes it possible to separate the fungal zoospores from its algal host cells. This procedure is particularly appropriate if the host alga is larger than the fungal zoospores $(2-3 \mu \mathrm{m})$. This method is useful not only to obtain fungal zoospores for experiments, but also to prevent the possible development of a resistant host strain (only zoospore suspensions are transferred to new host cultures, instead of using an infected host culture for inoculation of new host cultures, where the risk of transferring resistant hosts is increased). Culturing chytrids without host algae is also possible in artificial media (Barr \& Hickman, 1967b) or on agar plates (Barr, 1987). Both methods with or without host algae, how- ever, need special attention that bacteria should not outgrow the chytrids.

\section{Parameters for fungal infection}

The most common parameter quantifying the impact of chytrids on their host populations is the so-called prevalence of infection (proportion of infected cells, the percentages of infected cells) (Bruning et al., 1992; Holfeld, 2000a). This parameter is calculated by dividing the number of infected cells by the total number of host cells, and is often expressed as the percentages of infected cells. However, the prevalence of infection is not always the best parameter to quantify the severity of fungal attacks.

Another parameter to investigate the severity of fungal epidemics is the mean intensity of infection, which is a quantification of the mean number of fungi (attached zoospores and sporangia) per host cell in a population. This parameter is calculated by dividing the total number of fungi attached to algal cells by the total number of host cells (Holfeld, 2000a). This parameter normalizes the host cell density, and expresses how many fungi succeed in attachment to their host. Multiple infections (more than one parasite per host cell) can be expressed only by the mean intensity of infection. Multiple infections can have a large impact on host death rate, and to take this into account mean intensity of infection is more informative than the prevalence of infection.

A third important parameter is the abundance of free-swimming zoospores in lake water. This parameter has hardly been used, and only a few studies were carried out in natural lakes (Kudoh, 1990). This parameter may give an idea whether the prevalence of infection is dependent on the abundance of zoospores or on the successful attachment of the zoospores to the host cell.

Experimental studies (Bruning, 1991a, d, e) estimated four growth parameters to formulate a population dynamics model to calculate the specific growth rate of the chytrid at a given host density. The following parameters were included in the model: (1) the number of zoospores produced per sporangium; (2) the development time of the sporangia; (3) the infective lifetime of 
the zoospores; and (4) the infectivity constant, a measure for the effectivity of the mechanism by which zoospores find the host and infect it. From those four parameters, three new parameters can be calculated: (1) the maximum growth rate of the parasite, (2) the threshold host density for the development of an epidemic, and (3) the threshold host density for survival of the parasite (Bruning, 1991a, b).

\section{Phytoplankton-chytrids interactions}

\section{Host specificity}

Chytrids are often considered to be highly hostspecific parasites. However, the extent to which chytrids are truly host-specific has not been fully investigated. Some fungi are known to have narrow host ranges, while some had very broad host range (Gromov et al., 1999b).

The specific attachments of zoospores onto a particular host or group of algal species seem to indicate that specific signals are involved in the attraction of zoospores. Glycoproteins at the zoospore surface has been suggested to be the potential site involved in encystment or recognition of environmental cues (Powell, 1994). Marine (non-parasitic) chytrids species (Rhizophydium) were found to be positively attracted to both amino acids and carbohydrates (Muehlstein et al., 1988), indicating that chemical cues (chemotaxis) might be involved in recognizing potential host algae. Holfeld (2000b) suggested that zoospore losses on the wrong host are prevented because the attraction to cells is reversible. Recently, chemotaxis was suggested to be even strain specific by the experiments tracking the zoospores movement toward host cells. The swimming behavior of zoospores of the parasitic chytrid $Z$. planktonicum toward potential host algae ( $A$. formosa) was observed to differ between susceptible host strains and resistant ones (De Bruin et al. unpublished). However, further tests are needed to investigate the behavior of zoospores more thoroughly. In contrast, Canter \& Jaworski (1981) and Canter \& Jaworski (1982) found that the attraction of chytrid zoospores to algal hosts was not specific at all. Specifically, attraction of zoospores was recorded for a wide range of hosts, including diatoms, green algae and cyanobacteria. Host specificity would occur during encystment of the zoospores rather than at the earlier stage of chemotaxis (Doggett \& Porter, 1995). Zoospores of Z. planktonicum, a parasite of three Synedra species, sometimes loosely adhered to $A$. formosa, but germ tube intrusion was never observed (Doggett \& Porter, 1995). Since $Z$. planktonicum is a well-known parasite of $A$. formosa (see Ibelings et al., 2004), the findings of Doggett \& Porter (1995) also indicated that host selection in Z. planktonicum was confined to either Synedra or Asterionella, as reported by Canter \& Jaworski (1986) and Canter et al. (1992).

Host cell size versus fungal infection

A possible factor in the selection of potential hosts by the fungal zoospores may be host cell size, although this factor has not yet been well studied. Algal cell size has been found to be an important feature influencing phytoplankton loss factors in general, and has a major effect on vulnerability to zooplankton grazing and sinking rate (Smayda, 1970; Lampert, 1974; Sterner, 1989).

It might be possible that chytrids prefer larger host cells to small ones for several reasons. First, the larger host cells might cause an increase in parasite fecundity, because larger cells contain more resources, which might increase growth of the parasite. In fact, the final sporangium size and host cell size were found to be positively correlated (Holfeld, 2000a). Second, host species with a larger cell volume can be infected at a lower population density (Holfeld, 1998). As a result of being attracted to larger host algae, chytrids may escape from being grazed upon by zooplankton, if the infected host cells remain too large for zooplankton to be ingested (Kagami et al., 2005).

Infecting larger host cells might have some disadvantages for chytrids as well. Some chytrids (Rhizophydium planktonicum) are less infective at lower temperature and/or under low light / darkness (Bruning, 1991b). Therefore, if larger host cells sink faster to the deeper layers (cold and dark) of the lake (Smayda, 1970), fungal parasites may not be able to infect or complete their life cycle. 
It seems that parasitic chytrids prefer larger host species (Sommer, 1987). Large algae, which are fairly resistant to grazing by zooplankton, are often found being attacked by fungal parasites. In addition, fungal parasitism seems less likely on host cells of smaller size, especially picoplankton (Canter Lund \& Lund, 1995; Raven, 1998). The small size of these species may constitute too small contribution of resources for the completion of the parasite life cycle. In fact, chytrids infecting picoplankton have not been reported yet, although viruses attacking picoplankton species were reported (Suttle \& Chan, 1994; Wilson \& Mann, 1997; Bailey et al., 2004). In addition to cell size, colony formation (and especially colony forms) might have an impact on host selection, because chytrids can infect more than one cell of an algal filament by growing through the filament, or reach spatially distant host cells by means of branched rhizoids (Canter Lund \& Lund, 1995). Furthermore, zoospores may find neighboring host cells more easily if the host cells are arranged in a colony of some form. In some cases, parasitic chytrids were found to infect more $A$. formosa cells associated in colonies than the unicellular forms, and more parasitize A. formosa nonstellate colonies than stellate ones among colonies (Bertrand et al., 2004). However, more data are definitely needed to test this hypothesis.

Within host populations, size selectivity is still not clear. Some studies showed that infected cells tend to be larger than uninfected cells (Holfeld, 2000a), while other studies showed that smaller or intermediate size classes were more parasitized than larger ones (Koob, 1966; Sen, 1987a). Recently, susceptibility to fungal infection was found to be highly strain-specific within $A$. formosa host populations (De Bruin et al., 2004). Genetically different $A$. formosa strains differed in their susceptibility to parasite attack. Thus, not only host cell size but also its genetic make-up should be considered when size selectivity of chytrids within host populations is studied.

Fungal epidemics in the field

In lakes, phytoplankton blooms crashed relatively rapidly (over the course of a few weeks), at times when a high prevalence of infection (more than
90\%) with parasitic chytrids was observed (Van Donk \& Ringelberg, 1983; Kagami \& Urabe, 2002). Fungal infection on single algal species (or a small range of related species) may favor the development of other algal species. Thus fungal parasitism can be an important factor controlling phytoplankton seasonal succession. Fungal parasitism, however, has received less attention in controlling algal population dynamics compared to physic-chemical factors and grazing by zooplankton (Sommer et al., 1986). The marked effects of chytrids on natural phytoplankton populations and communities in lakes are: (1) delaying the timing of maximum algal numbers or decrease the size of peak population densities (Canter \& Lund, 1951), (2) the replacement of a dominant species by another species (Canter \& Lund, 1951; Reynolds, 1973; Van Donk \& Ringelberg, 1983), and (3) steering the outcome of interspecific competition among subdominant species (Canter \& Lund, 1969).

\section{Conditions for fungal epidemics}

The development of fungal epidemics is unpredictable and fluctuates with time and space. These fluctuations have been partly explained by abiotic factors, such as temperature (Barr \& Hickman, 1967a; Masters, 1971a; Blinn \& Button, 1973; Van Donk \& Ringelberg, 1983; Sen, 1987a; Kudoh \& Takahashi, 1990), light (Barr \& Hickman, 1967a; Blinn \& Button, 1973; Abeliovich \& Dikbuck, 1977; Kumar, 1978b; Canter \& Jaworski, 1979, 1981; Bruning, 1991b, d; Kagami \& Urabe, 2002), nutrients (Bruning, 1991a), pH (Sen, 1987a), turbulence (Doggett \& Porter, 1996; Kuhn \& Hofmann, 1999), and biotic factors, such as Daphnia grazing on fungal zoospores (Kagami et al., 2004). There are two contrasting statements concerning the necessary environmental conditions for the development of a fungal epidemic. One is that fungal epidemics within phytoplankton populations may arise more easily when growth conditions for the host are unfavorable (Canter \& Lund, 1948; Canter \& Lund, 1969; Masters, 1971a; Reynolds, 1984; Kagami \& Urabe, 2002). In contrast, Van Donk \& Ringelberg (1983) and Sen (1987a) observed that fungal epidemics occurred during optimal external conditions for the host. 
The development of a fungal epidemic depends on the specific growth rate of host and parasite populations. Fungal parasites can only become epidemic when the parasite population increases faster than the host population. Thus in theory, a fungal parasite may become epidemic under conditions when algal growth is depressed (for instance at low nutrient levels), or when fungal growth is enhanced (i.e., when host densities are high). If environmental factors depress fungal growth more than algal growth, this factor will obviously hamper epidemic development.

The response of fungal zoospores to environmental factors might be species-specific. For instance, zoospores of $R$. planktonicum were not able to find and infect their host under very low light conditions (Canter \& Jaworski, 1981; Bruning, 1991d), while zoospores of $R$. sphaerocarpum can infect their host even in the darkness (Barr \& Hickman, 1967a). These species-specific growth characteristics also make it difficult to generalize whether fungal epidemics may arise more easily when the growth conditions for the host are unfavorable or optimal.

Although experimental work by Bruning (1991a, b, d, e) showed that the direct effects of environmental factors on chytrids life history can be separated from indirect effects that affect the parasite via environmental effects on host density, it is still hard to specify exactly which factors determine fungal epidemics in the field. This may be explained by the fact that several environmental parameters commonly change simultaneously in aquatic systems. In addition, host density effects may override the effects of other factors (Kudoh \& Takahashi, 1990). Besides, several factors affect host-parasite dynamics in complex ways (Sen, 1988a; Bruning, 1991b; Doggett \& Porter, 1996). For instance, epidemics of a parasitic chytrid on its diatom host were favored by high light intensities when the water temperature was high, but low light intensities were required when the water temperature was low. However, epidemics were not possible below a certain threshold value of the host density, irrespective of temperature and light conditions (Bruning, 1991b).

It should also be noted that host cell mortality was not proportional to the fungal infection rate, and that mortality effects of the parasite varied according to environmental factors such as temperature (Kudoh \& Takahashi, 1990). Most previous studies have focused primarily on fungal dynamics (infection rates), and did not measure the mortality rate of the host algae (population decline rates). Host cells can be heavily infected by parasites and may still survive under high light conditions, whereas they would be more vulnerable (higher mortality) under reduced light (Kagami \& Urabe, 2002).

\section{Host defense}

One of the intriguing questions is: 'how can the host survive (and even bloom regularly), despite recurring epidemics with a high prevalence of infection $(>90 \%)$ by a highly virulent parasite? It is believed that a part of the host population escapes from infection, and serves as an inoculum for the next bloom. When a fungal epidemic reduces the host density to a very low number, it makes it hard for the parasite zoospores to find the last few remaining host cells. It has been shown for some diatom species that they form "seed banks" on the lake sediments, from where resuspended cells could provide the inoculum for the next bloom (Jewson, 1992; Itakura et al., 1997; McQuiod et al., 2002). These seedbanks are preserved under cold and dark conditions on the sediment, and this may enable the host to (temporarily) escape from parasite attack (Ibelings et al., 2004). These deeper lake areas might hence work as refuges for the host. Note that this is not always the case, that cysts of Ceratium were found infected only on the lake sediment and not while they were suspended in the water column (Canter Lund \& Lund, 1995).

Another form of defense of the host against parasite attack is a so-called hypersensitivity response. This type of defense is well described in (terrestrial) plant studies. The hypersensitivity response is a form of programmed cell death: a burst of superoxide production, and the expression of specific defense genes (White et al., 2000). A hypersensitive response in diatom $A$. formosa is characterized by a quick death of the algal host cell, shortly after infection (Canter Lund \& Lund, 1995). This way, the attached zoospores fail to 
develop into sporangia (Canter \& Jaworski, 1979), curbing epidemic development of the fungus.

Another type of defense, a form of induced chemical defense, was suggested by Pohnert (2000). The release of unsaturated aldehydes from mechanically wounded diatom cells (e.g. Asterionella and Thalassiossira) was shown to act as highly active fungicides against fungi like Schizophyllum and Aspergillus nidulans. The enzymatically produced unsaturated aldehydes, are also know to suppress copepod reproduction (Ianora et al., 2004). Rigorous tests are needed to examine whether these metabolites are effective against chytrids under natural conditions.

It is well known that some algae can defend themselves against grazers by changing their morphology (e.g., forming large colonies or aggregates or by producing spines) (Van Donk et al., 1999). Siliciumoxide $\left(\mathrm{SiO}_{2}\right)$, Calcium carbonate $\left(\mathrm{CaCO}_{3}\right)$, and certain polysaccharides in algal tissues were suggested to restrict the access of parasites, like viruses, amoebae, dinoflagellates and fungi to the host protoplast (Smetacek, 1999; Hamm et al., 2003; Raven \& Waite, 2004). However, silicification seems not to prevent the chytrids infection on diatom, because chytrids on diatoms are ecologically significant (Table 1). Chytrids penetrate the diatom protoplast using a rhyizoidal system (Van Donk \& Bruning, 1992), probably inserting a feeding tube between silicified wall segments (Fig. 1) after enzymic digestion of the organic components of the wall (Smetacek, 1999). Unlike the diatom cell, a porose silica wall with an overlapping system of girdle bands, there is only one entry point on siliceous Mallomonas cell or any other chrysophyte spore for the germ tube of the parasite (Canter Lund \& Lund, 1995). This entry is via the single hole in the cell wall which is plugged by non-siliceous matter. Even with this one entry point, fungal zoospores managed to settle themselves on the plug itself (Canter Lund \& Lund, 1995). Mucilage around cells doesn't seem to restrict the access of parasites to the protoplast either, because chytrids are also common on Sphaerocystis, Microcystis and Eudorina, in which fungi reaches algal cells by penetrating and elongating their threads through the mucilage into the protoplasts (Canter Lund \& Lund, 1995).
There may also be other evolutionary defense mechanisms by which algal host cells may protect themselves from parasite attack. The Red Queen hypothesis (Bell, 1982) states that the evolutionary struggle with parasites has selected for sexual reproduction among hosts, resulting in genetically variable offspring. High levels of genetic variation within $A$. formosa host populations from Lake Maarsseveen were found by the use of molecular markers (De Bruin et al., 2004). Every host strain was found to have a unique AFLP (amplified fragment length polymorphism) banding pattern, and these high levels of genetic variation may be explained by recombination (sexual reproduction). In addition it was demonstrated that genetically different host strains differed in their susceptibility to different isolates of the parasitic chytrid Z. planktonicum (Fig. 2) (De Bruin et al., 2004). Thus, as stated by the Red Queen hypothesis, algal hosts may maintain a high level of genetic diversity to fend off parasites and buffer their population against widespread epidemics. Furthermore, laboratory serial passage experiments using the Asterionella-Zygorhizidium system showed that parasite fitness during 200 generations of growth improved rapidly on a genetically uniform host population in comparison to a population constructed from multiple strains (De Bruin et al., submitted for publication). This indicates that a high level of genetic variation within host population may hold back parasite evolution. Although recombination through sexual reproduction is an important mechanism through which genetic diversity is created and maintained, sexual reproduction has never been observed in Asterionella populations (Maberly et al., 1994; Canter Lund \& Lund, 1995).

Multitrophic indirect defenses (Van Donk, 2005) have been described in many terrestrial and marine ecosystems (Dicke, 1999; Strom et al., 2003). These studies show that plants produce substances which attract natural enemies of the plant's attacker, resulting in an increase of predation on the herbivores, which in turn, reduces the grazing pressure of these herbivores on plants. In freshwater ecosystem, cyanobacteria were found to excrete organic substances that attract flagellates eating parasitic viruses of the 
Table 1 Chytrids and their host phytoplankton genera

\begin{tabular}{|c|c|c|c|}
\hline Host & $\begin{array}{l}\text { Cell } \\
\text { volume } \\
\left(\mu \mathrm{m}^{3}\right)\end{array}$ & Chytrids & Reference \\
\hline Anabaena & 94-320 & $\begin{array}{l}\text { Chytridium, Rhiozosiphon, Phlyctidium, } \\
\text { Blastocladiella, Scherffeliomyces }\end{array}$ & $\begin{array}{l}\text { 1, 12, } 13,14,16,22, \text { Paterson }(1960), \text { Canter \& } \\
\text { Willoughby (1964) }\end{array}$ \\
\hline Ankistrodesmus & $11-590$ & Zygorhizidium & 14 \\
\hline Ankyra & $3-67$ & Unidentified chytrids & Holfeld (1998) \\
\hline Aphanizomenon & $7-50$ & Chytridium, Phlyctidium, Rhizophidium & $12,22,24$ \\
\hline Apiocystis & & Rhizophidium & 10 \\
\hline Astericiccys & & Rhizophidium & 16 \\
\hline Asterionella & $350-650$ & $\begin{array}{l}\text { Chytridium, Chytriomyces, Rhizophidium, } \\
\text { Septosperma, Zygorhizidium, } \\
\text { unidentified chytrids }\end{array}$ & $\begin{array}{l}\text { 1, 14, 18, 23, 25, Beakes et al. }(1988,1992, \\
\text { 1993), Canter \& Jaworski (1978, 1979, } \\
\text { 1980), Kudoh \& Takahashi (1992), Sommer } \\
\text { (1987), Bertrand et al. (2004) }\end{array}$ \\
\hline Asterococcus & & Phlyctochytirium & 16 \\
\hline Betrachosperium & & Unidentified chytrids & 1 \\
\hline Botryococcus & 89 & Chytridium, unidentified chytrids & 1, Masters (1971b) \\
\hline Bulbochaete & & Chytridium & Sparrow (1936) \\
\hline Ceratium & $\begin{array}{l}29080- \\
\quad 62670\end{array}$ & Zygorhizidium, Rhizophydium & $\begin{array}{l}\text { 1, Canter \& Heaney (1984), Sommer (1987), } \\
\text { Heaney et al. (1988) }\end{array}$ \\
\hline Characium & & Chytridium, Rhizophydium & 1 \\
\hline Chaetoceros & & Rhizophydium & 26, Webster (1970) \\
\hline Chara & & Diplophlyctis, Entophlyctis & 13, Richard (1951) \\
\hline Chlamydocapsa & & Zygorhizidium & 1 \\
\hline Chlamydomonas & 650 & $\begin{array}{l}\text { Dangeardia, Entophlyctis, Polyphagus, } \\
\text { Phlyctochytirium, Rhizophidium, } \\
\text { Scherffeliomyces }\end{array}$ & $\begin{array}{l}\text { 13, 21, Johns (1964), Shin et al. (2001), Ingold } \\
\text { (1941) }\end{array}$ \\
\hline $\begin{array}{l}\text { Chlorococcalean } \\
\text { algae }\end{array}$ & & Rhizophydium & Gromov et al. (1999a) \\
\hline Chlorococcum & & Mesochytrium & Gromov et al. (2000) \\
\hline Chlorogronium & & Phlyctidium & 13 \\
\hline Chlorogonium & & Unidentified chytrids & 1 \\
\hline Chrysamoeba & 340 & Unidentified chytrids & Holfeld (1998) \\
\hline Chrysocapsa & & Dangeardia & 21 \\
\hline Chrysochaete & & Dangeardia & 20 \\
\hline Chrysomonad & & Rhizophidium & 14 \\
\hline Chrysophxis & & Rhizophidium & 14 \\
\hline Cladophora & & Olpidium, Phlyctochytirium, Rhizophidium & 13, Sparrow $(1936,1952)$ \\
\hline Closterium & $\begin{array}{l}820- \\
9200\end{array}$ & $\begin{array}{l}\text { Ancylistes, Entophlyctis, Micromycopsis, } \\
\text { Myzocytium, Micromyces, Olpidium, } \\
\text { Phlyctochytirium }\end{array}$ & $1,3,7,8,13,20$, Cook (1963) \\
\hline Cocconeis & 4600 & Chytridium & 4 \\
\hline Coelastrum & $610-780$ & Zygorhizidium & Sen $(1988 c)$ \\
\hline Cosmarium & 22000 & $\begin{array}{l}\text { Myzocytium, Phlyctochytirium, } \\
\text { Rhizophidium }\end{array}$ & $3,16,22,27$, Webster (1970) \\
\hline Cryptomonas & $\begin{array}{r}1700- \\
5337\end{array}$ & Rhizophydium & 19 \\
\hline Cyclotella & $\begin{array}{l}200- \\
3100\end{array}$ & Zygorhizidium & Sen $(1988 b)$ \\
\hline Cylindrocystis & & Endodesmidium & 7 \\
\hline Cylindrospermopsis & & Unidentified chytrids & Fabbro \& Duivenvoorden (1996) \\
\hline Dacrymyces & & Unidentified chytrids & Canter \& Ingold (1984) \\
\hline Desmidium & & Myzocytium & 4 \\
\hline Dictyosphaerium & $10-80$ & Rhizophydium, Zygorhizidium & 1, Sen $(1988 c)$ \\
\hline Dinobryon & $\begin{array}{l}2000- \\
4200\end{array}$ & Rhizophydium, Zygorhizidium & 9,14 \\
\hline Elakatothrix & 260 & Zygorhizidium & 14 \\
\hline Eremosphaera & & Olpidium, Rhizophydium & 13 \\
\hline
\end{tabular}


Table 1 continued

\begin{tabular}{|c|c|c|c|}
\hline Host & $\begin{array}{l}\text { Cell } \\
\text { volume } \\
\left(\mu \mathrm{m}^{3}\right)\end{array}$ & Chytrids & Reference \\
\hline Eudorina & $320-586$ & $\begin{array}{l}\text { Dangeardia, Endocoenobium, Polyphagus, } \\
\text { Rhizophydium, Zygorhizidium }\end{array}$ & 1, 2, 13, Ingold (1940), Johns (1964) \\
\hline Euglena & $\begin{array}{l}9700- \\
11000\end{array}$ & $\begin{array}{l}\text { Entophlyctis, Olpidium, Polyphagus, } \\
\text { Psuedosphaerita, Scherffeliomyces }\end{array}$ & $\begin{array}{l}\text { 13, Sparrow (1936), Anderson et al. (1995), } \\
\text { Johns (1964) }\end{array}$ \\
\hline Fragilaria & $300-755$ & $\begin{array}{l}\text { Chytridium, Podochytrium, Rhizophydium, } \\
\text { Zygorhizidium }\end{array}$ & $\begin{array}{l}\text { 4, 9, 25, Canter \& Jaworski (1982), Sommer } \\
\text { (1987), Sparrow (1936), Sen (1987b) }\end{array}$ \\
\hline Gemellicystis & & Rhizidium, Rhizophydium & $9,12,14$ \\
\hline Gonatozygon & & Myzocytium & 3,19 \\
\hline Heliozoa? & & Chytriomyces & 17 \\
\hline Hyalobryon & & Rhizophidium & 12,24 \\
\hline Hyalotheca & & Olpidium & 6 \\
\hline Kirchneriella & $7-110$ & Zygorhizidium & 1 \\
\hline Lyngbya & & Rhizophidium & 24 \\
\hline Mallomonas & $\begin{array}{l}940- \\
9000\end{array}$ & Chytridium, Pseudopileum, Septosperma & $1,21,25$ \\
\hline Melosira & $\begin{array}{l}190- \\
2000\end{array}$ & $\begin{array}{l}\text { Chytridium, Podochytrium, Rhyzidiopsis, } \\
\text { Rhizophydium, Zygorhizidium }\end{array}$ & $\begin{array}{l}\text { 10, 13, 18, Sparrow (1936), Sommer (1987), } \\
\text { Sen (1988b) }\end{array}$ \\
\hline Microcystis & $10-110$ & Chytridium, Rhizidium & $1,22, \operatorname{Sen}(1988 a)$ \\
\hline Mougeotia & $\begin{array}{l}1086- \\
27000\end{array}$ & $\begin{array}{l}\text { Chytridium, Micromyces, Olpidium, } \\
\text { Phlycidium, Zygorhizidium }\end{array}$ & $4,5,7,13$, Sparrow $(1936)$ \\
\hline Netrium & & Endodesmidium & 7 \\
\hline Nitella & & Chytridium, Diplophlyctis, Entophlyctis & 13, Sparrow (1936) \\
\hline Nitzschia & $310-320$ & Chytridium & 4 \\
\hline Ochromonas & 2800 & Chytridium & 1 \\
\hline Oedogonium & & Chytridium, Rhizophydium & $4,11,13$ \\
\hline Oocystis & $100-970$ & $\begin{array}{l}\text { Chytridium, Diplochytridium, Lagenidium, } \\
\text { Zygorhizidium }\end{array}$ & $\begin{array}{l}\text { Masters (1971a), Cook (1963), Sen (1988c), } \\
\text { Lopezllorca \& Hernandez (1996) }\end{array}$ \\
\hline Oscillatoria & $\begin{array}{l}130- \\
46600\end{array}$ & Rhizophidium & 12,22 \\
\hline Pandorina & 450 & Dangenardia, Polyphagus, Zygorhizidium & $\begin{array}{l}\text { 13, Sen (1988a), Johns (1964), Blinn \& Button } \\
\text { (1973), Blinn (1973) }\end{array}$ \\
\hline Pediastrum & $\begin{array}{l}910- \\
2200\end{array}$ & Phlyctidium, Zygorhizidium & Masters (1971c), Doggett \& Porter (1994) \\
\hline Penium & & Myzocytium & 3,21 \\
\hline Peridinium & 4700 & Amphicypellus, Phlyctochytirium & $\begin{array}{l}\text { 1, 14, 16, Ingold (1944), Alster \& Zohary } \\
\text { (2006) }\end{array}$ \\
\hline Pinnularia & & Podochytrium & 1 \\
\hline Pseudosphaerocystis & & Rhizophydium & 1 \\
\hline Pythium & & Rozella & 13 \\
\hline Rhizosolenia & 2000 & Zygorhizidium & $14,18,25$ \\
\hline Scenedesums & $92-440$ & Chytridium (Schenepf), Phlyctidium & $\begin{array}{l}\text { Lukavsky (1970), Abelovich \& Dikbuck } \\
\text { (1977), Masters (1971c), Puneva et al. } \\
\text { (2000) }\end{array}$ \\
\hline Sphaerocystis & 74 & Rhizophidium, Zygorhizidium & $1,10,12$ \\
\hline Spharozyga & & Chytridium & 22 \\
\hline Spirogyra & 31000 & $\begin{array}{l}\text { Chytridium, Entophlyctis, Lagenidium, } \\
\text { Micromyces, Phlyctochytirium, } \\
\text { Rhizidium, Rhizophydium }\end{array}$ & $\begin{array}{l}\text { 1, 2, 13, 27, Sparrow (1936), Webster (1970), } \\
\text { Masters (1971a), Paterson (1960), Barr \& } \\
\text { Hickman (1967a, b) }\end{array}$ \\
\hline Spirotaenia & & Rhizophydium & 5 \\
\hline Spondylosium & 10000 & Phlyctochytirium, Rhizophydium & 16, 22, Paterson (1960) \\
\hline Staurastrum & $\begin{array}{l}4920- \\
82000\end{array}$ & $\begin{array}{l}\text { Chytridium, Myzocytium, Phlyctochytirium, } \\
\text { Phlyctidium, Rhizophydium, } \\
\text { Zygorhizidium }\end{array}$ & $\begin{array}{l}3,14,15,16,20,21,22,27, \text { Sen }(1988 a) \\
\text { Webster (1970), Kagami \& Urabe (2002) }\end{array}$ \\
\hline Staurodesmus & & $\begin{array}{l}\text { Chytridium, Phlyctochytirium, } \\
\text { Rhizophydium }\end{array}$ & 1, 16, 27, Webster (1970) \\
\hline
\end{tabular}


Table 1 continued

\begin{tabular}{|c|c|c|c|}
\hline Host & $\begin{array}{l}\text { Cell } \\
\text { volume } \\
\left(\mu \mathrm{m}^{3}\right)\end{array}$ & Chytrids & Reference \\
\hline Stephanodiscus & $\begin{array}{l}220- \\
15980\end{array}$ & Zygorhizidium, unidentified chytrids & $\begin{array}{l}\text { Sommer (1987), Sen (1988b), Holfeld (2000a, } \\
\text { b) }\end{array}$ \\
\hline Stylosphaeridium & & Rhizophidium & 9 \\
\hline Synedra & $\begin{array}{l}160- \\
3800\end{array}$ & Septolpidium, Zygorhizidium & $13,14,18,25$ \\
\hline Tabellaria & 820 & Chytridium, Chytriomyces & 25 \\
\hline Tetmemorum & & Micromycopsis & 7 \\
\hline Tribonema & & Chytridium, Rhizophidium & 13, Sparrow (1936) \\
\hline Ulothrix & & Rhizophidium & 13 \\
\hline Uroglena & $98-150$ & Zygorhizidium & 9,14 \\
\hline Vaucheria & & Entophlyctis & 13, Sparrow (1936) \\
\hline Volvox & 60 & Polyphagus & 13, Johns (1964) \\
\hline Volvulina & & Polyphagus & Johns (1964) \\
\hline Xanthidium & 62000 & Myzocytium & 3,19 \\
\hline Zygnema & & Micromycopsis, Olpidium, Rhizophydium & 7,13 \\
\hline
\end{tabular}

References frequently used were shown by numbers: 1. Canter-Lund \& Lund (1995); 2. Canter (1946); 3. Canter (1947a); 4. Canter (1947b); 5. Canter (1947c); 6. Canter (1949a); 7. Canter (1949b); 8. Canter (1949c); 9. Canter (1950a); 10. Canter (1950b); 11. Canter (1950c); 12. Canter (1951); 13.Canter (1953); 14. Canter (1954); 15. Canter (1960); 16. Canter (1961); 17. Canter (1966); 18. Canter (1967); 19. Canter (1968); 20. Canter (1969); 21. Canter (1971); 22. Canter (1972); 23. Canter \& Lund (1948); 24. Canter \& Lund (1951); 25. Canter \& Lund (1953); 26. Canter \& Lund (1968); 27. Canter \& Lund (1969). The range of host cell volumes are listed if the data is available (Reynolds, 1984; Ichise et al., 1995; Kagami \& Urabe, 2001)

cyanobacteria (Murray, 1995). It is possible that algae might also excrete some kind of infochemical, which may attract enemies (predators or parasites) of chytrids. Predation on the zoospores of chytrids has been found for certain zooplankton species, like Daphnia, the ciliate Cyclidium, and the Chrysophyte Ochromonas (Canter Lund \& Lund, 1995; Kagami et al., 2004). Hyperparasitism, parasites infecting parasites, was found for

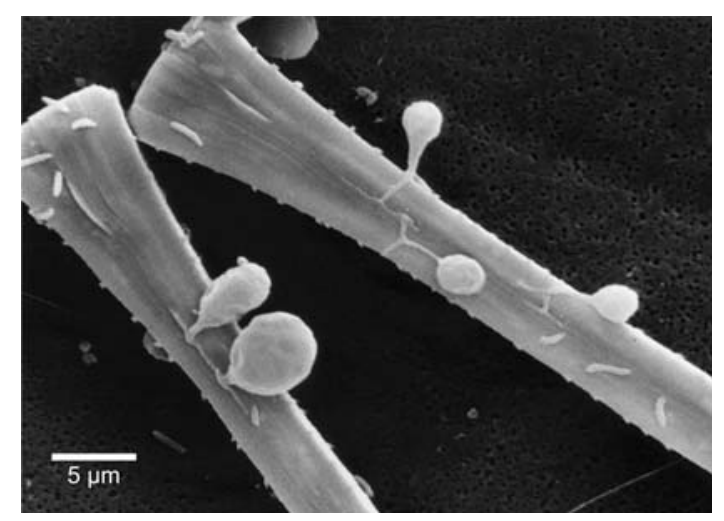

Fig. 1 Scanning electron microscopy image of $A$. formosa cells (rod-shapes) infected by Z. planktonicum (spheres). Photo by Van Donk the chytrid Zygorhizidium affluens. This parasite was frequently parasitized by another chytrid Rozella sp. (Canter, 1969). Although the impact

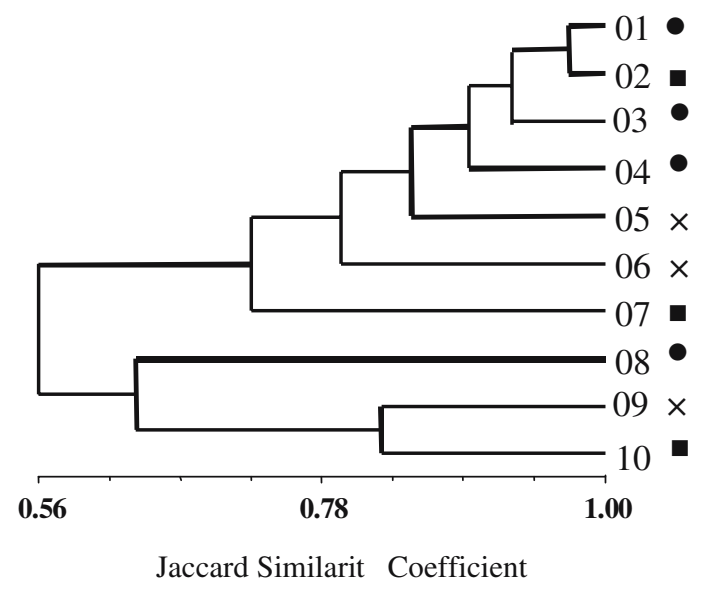

Fig. 2 Genotypic similarity among Asterionella formosa strains isolated from Lake Maarsseveen, obtained by AFLP fingerprinting (modified after De Bruin et al., 2004). Susceptibilities to parasite attack by Zygorhizidium planktonicum from Lake Maarsseveen differ among host strains, indicated as: $(\bullet)$ highly susceptible, (ロ) moderately susceptible, and $(\times)$ resistant 
of these hyperparasites was not high enough to save the parasitized algae from their death (Canter Lund \& Lund, 1995), hyperparasitism can reduce the impact of a fungal infection by reducing the production of spores by the primary parasite.

\section{Impact of chytrids on food web dynamics}

Parasites are generally neglected in food web studies, although their importance in food web dynamics has been emphasized by Marcogliese and Cone (1997). Recently, a new possible role of chytrids in aquatic food webs has been put forward. It has been suggested that the zoospores of chytrids are a good food source for zooplankton like Daphnia (Kagami et al., 2004). Zoospores of the chytrid $Z$. planktonicum, the fungal parasite of $A$. formosa, were found to be grazed efficiently by Daphnia (Kagami et al., 2004), since their size $(2-3 \mu \mathrm{m})$ was well within the preferred range of food particle size for zooplankton (Geller \& Müller, 1981). The density of zoospores during an epidemic may be in the same order of magnitude (or even more) than the density of edible phytoplankton cells (i.e., several thousands per milliliter). This implies that fungal zoospores may be a food source of some importance for Daphnia during fungal epidemics.

Phytoplankton species that are susceptible to fungal infection seem to be mainly large species, which are less grazed by large zooplankton (Sommer, 1987). Our experiments revealed that under the dominance of inedible algae (Asterionella), Daphnia could grow and survive well (only) if zoospores of the parasitic fungus were present (Kagami et al. unpublished). Since the infected Asterionella colonies remained inedible for Daphnia (Kagami et al., 2005), the higher growth rates in the treatments with fungi should be ascribed to grazing on fungal zoospores. The results indicate that fungi may enhance the reproduction and growth of Daphnia, especially when large inedible phytoplankton species dominate the phytoplankton community.

Large phytoplankton species are believed to be lost by sinking from the euphotic zone instead of being grazed (Malone, 1980; Legendre \& Le Fevre, 1991; Kiørboe, 1993). When these large inedible phytoplankton species are infected by fungi, however, nutrients within these cells are consumed by parasitic fungi, some of which in turn are grazed by Daphnia. This new pathway has been dubbed the 'Mycoloop' since nutrients from large inedible algae are transferred to zooplankton via the zoospores of parasitic fungi that have 'consumed' nutrients from their algal hosts. The mycoloop may occasionally play an important role in shaping aquatic systems, by altering the material flow from settled algae to cells that are available to the pelagic food webs (Fig. 3).

One of the remarkable characteristics of fungal zoospores is the possession of an oil globule (Canter, 1967). Lipid analyses of fungal zoospores revealed that fungal zoospores are rich in polyunsaturated fatty acids (PUFAs), and contain high cholesterol concentrations (Kagami et al., unpublished). The analyses support the idea that fungal zoospores are food of good quality for Daphnia, since PUFAs and cholesterols are known to be essential for Daphnia growth and reproduction (Müller-Navarra et al., 2000). Thus, fungi might facilitate the growth of zooplankton not only via transferring energy (nutrients) from inedible algae to zooplankton, but also due to high nutritional quality of the chytrids themselves.

\section{Future perspectives}

It is essential to collect more data to obtain a better insight in the general patterns of the fungal distribution in aquatic ecosystems and to test/ confirm the ideas described above. In lakes, for instance, estimating zoospore abundance is especially needed in addition to the data on the prevalence of infection. Furthermore, the presence and the roles of chytrids have not yet been investigated in marine and river ecosystems. Only a few chytrids have been found in estuary (Kazama, 1972) and on marine diatoms, such as Licmophora hyaline (Kumar, 1978a; Kumar, 1980) and Coscinodiscus oculus iridis (Taylor, 1976). Chytrids are also known on marine algae 


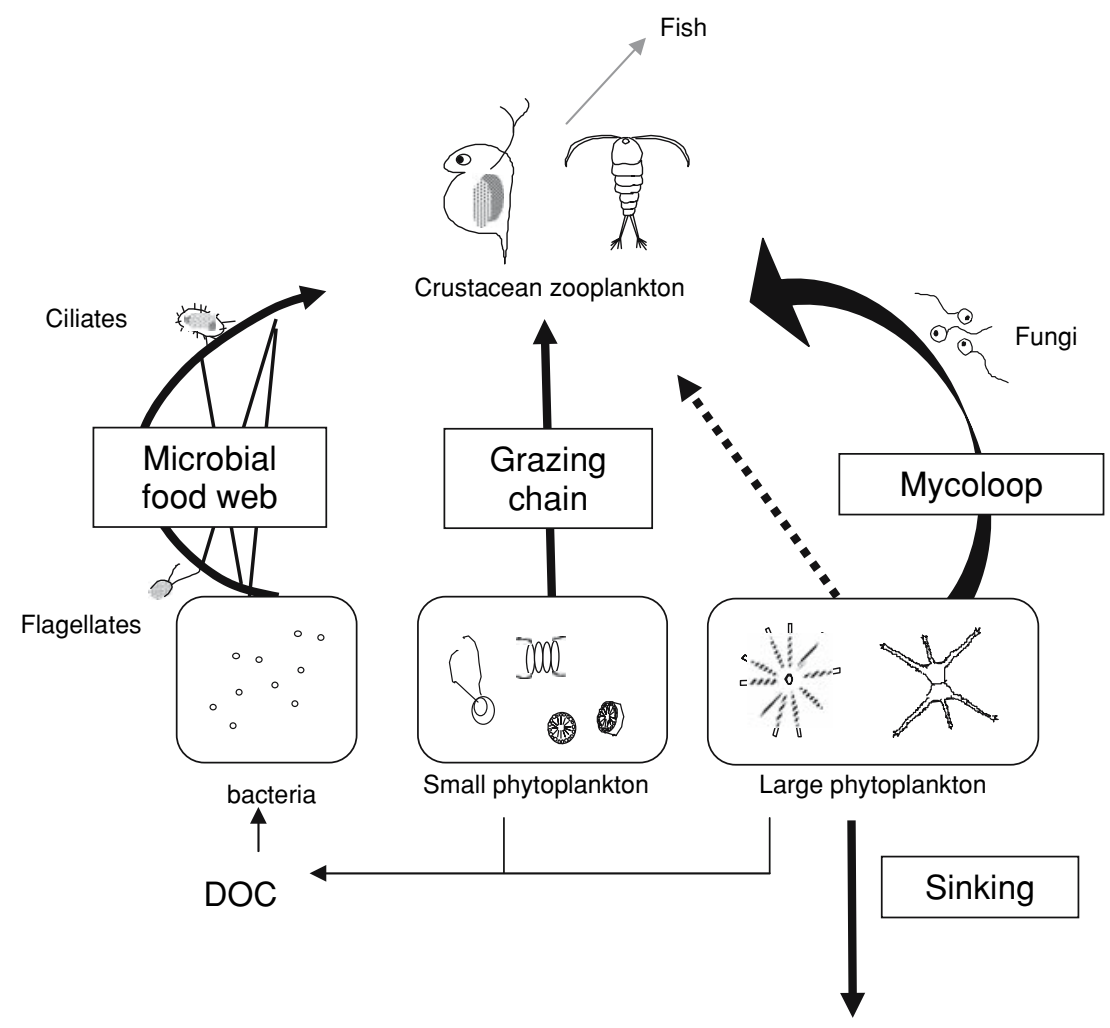

Fig. 3 Diagram of planktonic food webs. Large inedible algae can be incorporated into food webs instead of sinking to the lake bottom, if they are infected by chytrids,

Cladophora (Raghukumar, 1986). In addition, in a river, a single chytrid has been reported (Fabbro \& Duivenvoorden, 1996).

The key drivers of aquatic ecosystem change (eutrophication, increasing temperature and UV radiation, habitat alteration, invasive species and pollution) may alter the impact of parasites on their host populations. Since fungal parasites perform better during diatom blooms that occur during warmer springs (Van Donk \& Ringelberg, 1983), climate change may enhance fungal growth, which might increase the importance of fungal parasites in ecosystems. Some phytoplankton species may become more susceptible to chytrids due to the increase of UV radiation, as reported for instance in a chytrid-amphibians relationship (Blaustein et al., 1994; Blaustein \& Kiesecker, 2002).

Some stressors may also increase host density, which increases the encounter rate between host and parasites. Eutrophication due to habitat some of which in turn are grazed by Daphnia. This new pathway is named as "Mycoloop"

alteration has been suggested as a driver of elevated parasitic infection in amphibian populations (Johnson \& Chase, 2004). Specifically, eutrophication might cause a shift in snails species composition towards the potential host species (Planorbella spp.) of the chytrid Ribeiroia ondatrae, which increased amphibian malformation caused by Ribeiroia infection (Johnson \& Chase, 2004). If eutrophication increases the abundance of large inedible algae as predicted by models (Leibold, 1989; Grover, 1995; Leibold, 1996), thus it may increase the impact of chytrids, since large inedible algae seem to be common as hosts to parasitic chytrids (Sommer, 1987). Furthermore, under environmental stress the host range of parasites may change, bringing completely new phytoplankton taxa under parasite attack. Longterm data, paleolimnological analysis and experiments may provide the evidence for the impact of environmental fluctuations on phytoplanktonchytrids interactions. 
Acknowledgements We are grateful to Meric Albay who arranged the 14th IAP meeting in Turkey and invite M. Kagami to give this plenary lecture. We thank $M$. Rijkerboer and M. Brehm for their support to progress our fungal work. This study was partly supported by a research fellowship from the Japan Society for the Promotion of Science for Young Scientists.

\section{References}

Abeliovich, A. \& S. Dikbuck, 1977. Factors affecting infection of Scenedesmus-obliquus by a Chytridium $\mathrm{sp}$ in sewage oxidation ponds. Applied and Environmental Microbiology 34: 832-836.

Alster, A. \& T. Zohary, 2007. Interactions between the bloom-forming dinoflagellate Peridinium gatunense and the chytrid fungus Phlyctochytrium sp. Hydrobiologia 578: 131-139.

Anderson, S. A., A. Stewart \& G. T. Allen, 1995. Pseudosphaerita euglenae, a fungal parasite of euglena spp in the mangere oxidation ponds, auckland, newzealand. New Zealand Journal of Marine and Freshwater Research 29: 371-379.

Bailey, S., M. R. J. Clokie, A. Millard \& N. H. Mann, 2004. Cyanophage infection and photoinhibition in marine cyanobacteria. Research in Microbiology 155: 720725.

Barr, D. J. S., 1987. Isolation, Culture, and Identificaiton of Chytridiales, Spizellomycetales, and Hyphochytriales. Southeastern Publishing Corporation, Athens, GA.

Barr, D. J. S., \& C. J. Hickman, 1967a. Chytrids and algae. II. Factors influencing parasitism of Rhizophydium sphaerocarpum on Spirogyra. Canadian Journal of Botany 45: 431-440.

Barr, D. J. S. \& C. J. Hickman, 1967b. Chytrids and algae. I. Host-substrate range and morphological variation of species of Rhizophydium. Canadian Journal of Botany 45: 423-430.

Beakes, G. W., H. M. Canter \& G. H. M. Jaworski, 1988. Zoospore ultrastructure of Zygorhizidium affuens and $Z$. planktonicum, two chytrids parasitizing the diatom Asterionella-formosa. Canadian Journal of Botany 66: 1054-1067.

Beakes, G. W., H. M. Canter \& G. H. M. Jaworski, 1992. Comparative ultrastructural ontogeny of zoosporangia of Zygorhizidium affuens and Z. planktonicum, chytrid parasites of the diatom Asterionella-formosa. Mycological Research 96: 1047-1059.

Beakes, G. W., H. M. Canter \& G. H. M. Jaworski, 1993. Sporangium differentiation and zoospore fine-structure of the chytrid Rhizophydium-planktonicum, a fungal parasite of Asterionella-formosa. Mycological Research 97: 1059-1074.

Bell, G., 1982. The Masterpiece of Nature: The Evolution and Genetics of Sexuality. University of California Press, Berkeley/Los Angeles.

Bertrand, C., A. Coute \& A. Cazaubon, 2004. Fungal parasitism of the diatom Asterionella formosa hassall (bacillariophyceae) by Chytridiomycota. Annales de Limnologie-International Journal of Limnology 40: 63-69.

Blaustein, A. R., P. D. Hoffman, D. G. Hokit, J. M. Kiesecker, S. C. Walls \& J. B. Hays, 1994. UV repair and resistance to solar UV-b in amphibian eggs-a link to population declines. Proceedings of The National Academy of Sciences of The United States of America 91: 1791-1795.

Blaustein, A. R. \& J. M. Kiesecker, 2002. Complexity in conservation: lessons from the global decline of amphibian populations. Ecology Letters 5: 597-608.

Blinn, D. W., 1973. Effect of light and temperature on parasitism of Pandorina sp. by Dangeardia-mammillata-b schroder in an arizona mountain lake. Journal of Phycology 9: 4-4.

Blinn, D. W. \& K. S. Button, 1973. Effect of temperature on parasitism of Pandorina sp. by Dangeardia-mammillata-b schroder in an arizona mountain lake. Journal of Phycology 9: 323-326.

Bowman, B. H., J. W. Taylor, A. G. Brownlee, J. Lee, S. D. Lu \& T. J. White, 1992. Molecular evolution of the fungi-relationship of the Basidiomycetes, Ascomycetes, and Chytridiomycetes. Molecular Biology and Evolution 9: 285-296.

Bruning, K., 1991a. Effects of phosphorus limitation on the epidemiology of a chytrid phytoplankton parasite. Freshwater Biology 25: 409-417.

Bruning, K., 1991b. Effects of temperature and light on the population-dynamics of the Asterionella-Rhizophydium association. Journal of Plankton Research 13: 707-719.

Bruning, K., 1991c. Fungal parasitism in phytoplankton populations. University of Amsterdam, Amsterdam.

Bruning, K., 1991d. Infection of the diatom Asterionella by a chytrid. 1. Effects of light on reproduction and infectivity of the parasite. Journal of Plankton Research 13: 103-117.

Bruning, K., 1991e. Infection of the diatom Asterionella by a chytrid. 2. Effects of light on survival and epidemic development of the parasite. Journal of Plankton Research 13: 119-129.

Bruning, K., R. Lingeman \& J. Ringelberg, 1992. Estimating the impact of fungal parasites on phytoplankton populations. Limnology and Oceanography 37: 252 260.

Canter, H. M., 1946. Studies on British chytrids. I. Dangeardia mammillata Schrödor. Transactions of the British Mycological Society 29: 128-134.

Canter, H. M., 1947a. On Mysocytium megastomum DeWildeman. Transactions of the British Mycological Society 31: 80-84.

Canter, H. M., 1947b. Studies on British chytrids. II. Some new monocentric chytrids. Transactions of the British Mycological Society 31: 94-105.

Canter, H. M., 1947c. Studies on British chytrids. III. Zygorhizidium willei Löwenthal and Rhizophydium columanaris n. Sp. Transactions of the British Mycological Society 31: 128-135.

Canter, H. M., 1949a. Studies on British chytrids. V. On Olpidium hyalothecae Scherffel and Olpidium 
ultriculiforme Scherffel. Transactions of the British Mycological Society 32: 22-29.

Canter, H. M., 1949b. Studies on British chytrids. VI. Aquatic Synchytriaceae. Transactions of the British Mycological Society 32: 69-94.

Canter, H. M., 1949c. Studies on British chytrids. VII. On Phlyctochytrium mucronatum n. sp. Transactions of the British Mycological Society 32: 236-240.

Canter, H. M., 1950a. Fungal parasites of the phytoplankton .I. Studies on British chytrids X. Annals of Botany 14: 263-289.

Canter, H. M., 1950b. Studies on British chytrids. VIII. On Rhizophydium anomalum n. sp. New Phytologist 49: 98-102.

Canter, H. M., 1950c. Studies on British chytrids. XI. Chytridium oedogonii couch. Transactions of the British Mycological Society 33: 354-358.

Canter, H. M., 1951. Studies on British chytrids. XII. Fungal parasites of the phytoplankton 2. Annals of Botany 15: 129-\&.

Canter, H. M., 1953. Annotated list of British aquatic chytrids. Transactions of the British Mycological Society 36: 278-303.

Canter, H. M., 1954. Fungal parasites of the phytoplankton. III. The studies on British chytrids. XIII. Transactions of the British Mycological Society 37: 111-133.

Canter, H. M., 1960. Fungal parasites of the phytoplankton. V. Chytridium isthmophilum sp. Nov. Transactions of the British Mycological Society 43: 660-664.

Canter, H. M., 1961. Studies on British chytrids. XVII. Species occurring on planktonic desmids. Transactions of the British Mycological Society 44: 163-176.

Canter, H. M., 1966. Studies on British chytrids XXV. Chytriomyces heliozoicola sp nov a parasite of Heliozoa in plankton. Transactions of the British Mycological Society 49: 633.

Canter, H. M., 1967. Studies on British chytrids XXVI. A critical examination of Zygorhizidium melosirae canter and Z. planktonicum canter. Biological Journal of the Linnean Society 60: 85-97.

Canter, H. M., 1968. Studies on British chytrids. XXVII. Rhizophydium fugax sp nov a parasite of Planktonic cryptomonads with additional notes and records of planktonic fungi. Transactions of the British Mycological Society 51: 699.

Canter, H. M., 1969. Studies on British chytrids. XXIX. A taxonomic revision of certain fungi found on the diatom Asterionella. Biological Journal of the Linnean Society 62: 267-278.

Canter, H. M., 1971. On Zygorhizidiu venustrum (Canter) n. comb. together with an illustrated list of chytrids occurring on chrysophycean algae. Nova Hedwigia 21: 577-597.

Canter, H. M., 1972. A guide to the fungi occurring on planktonic blue-green algae. In Desilachary $\mathrm{T}$. V. (ed.), Taxonomy and Biology of Blue-Green Algae. University of Madras, Madras: 145-158.

Canter, H. M. \& S. I. Heaney, 1984. Observations on zoosporic fungi of Ceratium spp. in lakes of the English lake district; Importance for phytoplankton population dynamics. New Phytologist 97: 601-612.
Canter, H. M. \& C. T. Ingold, 1984. A chytrid on Dacrymyces. Transactions of the British Mycological Society 82: 739-742.

Canter, H. M. \& G. H. M. Jaworski, 1978. Isolation, maintenance and host range studies of a chytrid Rhizophydium-planktonicum Canter emend, parasitic on Asterionella-formosa Hassall. Annals of Botany 42: 967-979.

Canter, H. M. \& G. H. M. Jaworski, 1979. Occurrence of a hypersensitive reaction in the planktonic diatom Asterionella-formosa Hassall parasitized by the chytrid Rhizophydium-planktonicum Canter emend., in culture. New Phytologist 82: 187-206.

Canter, H. M. \& G. H. M. Jaworski, 1980. Some general observations on zoospores of the chytrid Rhizophydium planktonicum Canter emend. New Phytologist 84: 515-531.

Canter, H. M. \& G. H. M. Jaworski, 1981. The effect of light and darkness upon infection of Asterionellaformosa Hassall by the chytrid Rhizophydium-planktonicum Canter emend. Annals of Botany 47: 13-30.

Canter, H. M. \& G. H. M. Jaworski, 1982. Some observations on the alga Fragilaria-crotonensis Kitton and its parasitism by 2 chytridiaceous fungi. Annals of Botany 49: 429-446.

Canter, H. M. \& G. H. M. Jaworski, 1986. A study on the chytrid Zygorhizidium-planktonicum Canter, a parasite of the diatoms Asterionella and Synedra. Nova Hedwigia 43: 269-298.

Canter, H. M., G. H. M. Jaworski \& G. W. Beakes, 1992. Formae speciales differentiation in the chytrid Zygorhizidium planktonicum Canter, a parasite of the diatoms Asterionella and Synedra. Nova Hedwigia 55: 437-455.

Canter, H. M. \& J. W. G. Lund, 1948. Studies on plankton parasites .I. Fluctuations in the numbers of Asterionella-formosa Hass in relation to fungal epidemics. New Phytologist 47: 238-261.

Canter, H. M. \& J. W. G. Lund, 1951. Studies on plankton parasites. III. Examples of the interaction between parasitism and other factors determining the growth of diatoms. Annals of Botany 15: 359-371.

Canter, H. M. \& J. W. G. Lund, 1953. Studies on plankton parasites. II. The parasitism of diatoms with special reference to lakes in the English lake district. Transactions of the British Mycological Society 36: 13-37.

Canter, H. M. \& J. W. G. Lund, 1968. The importance of protozoa in controlling the abundance of planktonic algae in lakes. Proceedings for Linnean Society of London 179: 203-219.

Canter, H. M. \& J. W. G. Lund, 1969. Parasitism of planktonic desmids by fungi. Osterreichische Botanische Zeitschrift 116: 351-377.

Canter, H. M. \& L. G. Willoughby, 1964. A parasitic Blastocladiella from Windermere plankton. Journal of Royal Microscopic Society 83: 365-372.

Canter Lund, H. M. \& J. W. G. Lund, 1995. Freshwater algae: Their microscopic world explored. Biopress, UK.

Cook, P. W., 1963. Host range studies of certain Phycomycetes parasitic on desmids. American Journal of Botany 50: 580-588. 
De Bruin, A., B. W. Ibelings, M. Rijkeboer, M. Brehm \& E. van Donk, 2004. Genetic variation in Asterionella formosa (bacillariophyceae): Is it linked to frequent epidemics of host-specific parasitic fungi? Journal of Phycology 40: 823-830.

Dicke, M., 1999. Evolution of induced indirect defence of plants. In Tollrian R. \& C. D. Harvell (eds), Ecology and Evolution of Inducible Defenses. Princeton University Press, Princeton, 62-88.

Doggett, M. S. \& D. Porter, 1994. Observations of Zygorhizidium sp parasitic on Pediastrum-duplex. Mycologia 86: 199-202.

Doggett, M. S. \& D. Porter, 1995. Further evidence for host-specific variants in Zygorhizidium-planktonicum. Mycologia 87: 161-171.

Doggett, M. S., \& D. Porter, 1996. Sexual reproduction in the fungal parasite, Zygorhizidium planktonicum. Mycologia 88, 720-732.

Fabbro, L. D. \& L. J. Duivenvoorden, 1996. Profile of a bloom of the cyanobacterium Cylindrospermopsis raciborskii (Woloszynska) seenaya and subba raju in the fitzroy river in tropical central queensland. Marine and Freshwater Research 47: 685-694.

Geller, W. \& H. Müller, 1981. The filtration apparatus of cladocera: Filter mesh-sizes and their implications of food selectivity. Oecologia 49: 316-321.

Gromov, B. V., K. A. Mamkaeva \& A. V. Pljusch, 2000. Mesochytrium penetrans Gen. Et sp. Nov. (chytridiales) - a parasite of the green alga Chlorococcum minutum (chlorococcales), with an unusual behaviour of the sporangia. Nova Hedwigia 71: 151-160.

Gromov, B. V., A. V. Pljusch \& K. A. Mamkaeva, 1999a. Cultures of Rhizophydium spp. (chytridiales)-parasites of chlorococcalean algae. Algological Studies 95: 115-123.

Gromov, B. V., A. V. Pljusch \& K. A. Mamkaeva, 1999 b. Morphology and possible host range of Rhyizophydium algavorum sp. Nov. (chytridiales)—and obligate parasite of algae. Protistology 1: 62-65.

Grover, J. P., 1995. Competition, herbivory, and enrichment-nutrient-based models for edible and inedible plants. American Naturalist 145: 746-774.

Hamm, C. E., R. Merkel, O. Springer, P. Jurkojc, C. Maier, K. Prechtel \& V. Smetacek, 2003. Architecture and material properties of diatom shells provide effective mechanical protection. Nature 421: 841-843.

Heaney, S. I., J. W. G. Lund, H. M. Canter \& K. Gray, 1988. Population dynamics of Ceratium spp. in three English lakes, 1945-1985. Hydrobiologia 161: 133-148.

Holfeld, H., 1998. Fungal infections of the phytoplankton: Seasonality, minimal host density, and specificity in a mesotrophic lake. New Phytologist 138: 507-517.

Holfeld, H., 2000a. Infection of the single-celled diatom Stephanodiscus alpinus by the chytrid Zygorhizidium: Parasite distribution within host population, changes in host cell size, and host-parasite size relationship. Limnology And Oceanography 45: 1440-1444.

Holfeld, H., 2000b. Relative abundance, rate of increase, and fungal infections of freshwater phytoplankton. Journal of Plankton Research 22: 987-995.
Ianora, A., A. Miralto, S. A. Poulet, Y. Carotenuto, I. Buttino, G. Romano, R. Casotti, G. Pohnert, T. Wichard, L. Colucci-D'Amato, G. Terrazzano, \& V. Smetacek, 2004. Aldehyde suppression of copepod recruitment in blooms of a ubiquitous planktonic diatom. Nature 429: 403-407.

Ibelings, B. W., A. De Bruin, M. Kagami, M. Rijkeboer, M. Brehm \& E. van Donk, 2004. Host parasite interactions between freshwater phytoplankton and chytrid fungi (Chytridiomycota). Journal of Phycology 40: 437-453.

Ichise, S., T. Wakabayashi, Y. Matsuoka, S. Yamanaka, N. Fujiwara \& K. Tanaka, 1995. A simple method for the estimation of phytoplankton biomass based on cell morphology in Lake Biwa. Report of Shiga Prefectural Institute of Public Health and Environmental Science 30: 26-35.

Ingold, C. T., 1940. Endocoenbium eudorinae Gen. et sp. Nov., a chytridiaceous fungus parasitizing Eudorina elegans Ehrenb. New Phytologist 39: 97-103.

Ingold, C. T., 1941. Studies on British chytrids. I. Phlyctochytrium proliferum sp. Nov. and Rhizophydium lecythii sp. Nov. Transactions of the British Mycological Society 25: 41-48.

Ingold, C. T., 1944. Studies on British chytrids. II. A new chytrid on Ceratium and Peridinium. Transactions of the British Mycological Society 27: 93-96.

Itakura, S., I. Imai \& K. Itoh, 1997. "Seed bank" of coastal planktonic diatoms in bottom sediments of Hiroshima Bay, seto inland sea, Japan. Marine Biology 128: 497 508 .

Jewson, D. H., 1992. Size-reduction, reproductive strategy and the life-cycle of a centric diatom. Philosophical Transactions of The Royal Society of London Series B-Biological Sciences 336: 191-213.

Johns, R. M., 1964. A new polyphagus in algal culture. Mycologia 56: 441-451.

Johnson, P. T. J. \& J. M. Chase, 2004. Parasites in the food web: Linking amphibian malformations and aquatic eutrophication. Ecology Letters 7: 521-526.

Kagami, M., B. W. Ibelings, A. De Bruin \& E. Van Donk, 2005. Vulnerability of Asterionella formosa to daphnia grazing: Impact of a fungal parasite. Verhandlungen IVL 29: 350-354.

Kagami, M. \& J. Urabe, 2001. Phytoplankton growth rate as afunction of cell size: an experimental test in Lake Biwa. Limnology 2: 111-117.

Kagami, M. \& J. Urabe, 2002. Mortality of the planktonic desmid, Staurastrum dorsidentiferum, due to interplay of fungal parasitism and low light conditions. Verhandlungen IVL 28: 1001-1005.

Kagami, M., E. Van Donk, A. de Bruin, M. Rijkeboer \& B. W. Ibelings, 2004. Daphnia can protect diatoms from fungal parasitism. Limnology and Oceanography 49: 680-685.

Kazama, F. Y., 1972. Ultrastructure and phototaxis of zoospores of Phlyctochytrium sp, an estuarine chytrid. Journal of General Microbiology 71: 555-566.

Kiørboe, T., 1993. Turbulence, phytoplankton cell-size, and the structure of pelagic food webs. Advances in 
Marine Biology, Vol 29 Advances in Marine Biology 29: $1-72$.

Koob, D. B., 1966. Parasitism of Asterionella formosa Hass by a chytrid in two lakes of Rawah wild area of Colorado. Journal of Phycology 2: 41-45.

Kudoh, S. 1990. Studies on the population control mechanisms of a planktonic diatom, Asterionella formosa Hassall, by fungal parasitism in natural waters. University of Tokyo.

Kudoh, S. \& M. Takahashi, 1990. Fungal control of population-changes of the planktonic diatom Asterionella-formosa in a shallow eutrophic lake. Journal of Phycology 26: 239-244.

Kudoh, S. \& M. Takahashi, 1992. An experimental test of host population size control by fungal parasitism in the planktonic diatom Asterionella formosa using mesocosms in a natural lake. Archiv fur Hydrobiologie 124: 293-307.

Kuhn, S. F. \& M. Hofmann, 1999. Infection of Coscinodiscus granii by the parasitoid nanoflagellate Pirsonia diadema. III. Effects of turbulence on the incidence of infection. Journal of Plankton Research 21: 2323-2340.

Kumar, C. R., 1978a. Auxospore formation in species of the marine diatom Licmophora agardh. Veroffentlichungen des Instuts fur Meeresforschungin Bremerhaven 17: 15-20.

Kumar, C. R., 1978b. Physiology of infection of the marine diatom Licmophora by the fungus Ectrogella perforans. Veroffentlichungen des Instuts fur Meeresforschungin Bremerhaven 17: 1-14.

Kumar, C. R., 1980. An ultrastructural-study of the marine diatom Licmophora-hyalina and its parasite Ectrogella-perforans. 1. Infection of host-cells. Canadian Journal of Botany-Revue Canadienne De Botanique 58: $1280-1290$.

Lampert, W., 1974. A method for determination of food selection by zooplankton. Limnology and Oceanography 18: 995-998.

Legendre, L. \& J. Le Fevre, 1991. From individual plankton cells to pelagic ecosystems and to global biogeochemical cycles. In Demers S. (ed.), Particle Analysis in Oceanography. Springer-Verlag, Berlin, 261-300.

Leibold, M. A., 1989. Resource edibility and the effects of predators and productivity on the outcome of trophic interactions. American Naturalist 134: 922-949.

Leibold, M. A., 1996. A graphical model of keystone predators in food webs: trophic regulation of abundance, incidence, and diversity patterns in communities. American Naturalist 147: 784-812.

LopezLlorca, L. V. \& P. Hernandez, 1996. Infection of the green alga Oocystis lacustris chod with the chytrid fungus Diplochytridium deltanum (Masters) Karling. An SEM study. Micron 27: 355-358.

Lukavsky, J., 1970. Phlyctidium scenedesmi, a chytrid destroying an outdoor mass culture of Scenedesmus obliqus. Nova Hedwigia 19: 775-777.

Maberly, S. C., M. A. Hurley, C. Butterwick, J. E. Corry, S. I. Heaney, A. E. Irish, G. H. M. Jaworski, J. W. G. Lund, C. S. Reynolds \& J. V. Roscoe, 1994. The rise and fall of Asterionella-formosa in the south basin of
Windermere-analysis of a 45-year series of data. Freshwater Biology 31: 19-34.

Malone, T. C., 1980. Algal size. In Morris I. (ed), The Physiological Ecology of Phytoplankton. University of California Press, Berkeley/Los Angeles: 433-463.

Marcogliese, D. J. \& D. K. Cone, 1997. Food webs: A plea for parasites. Trends in Ecology \& Evolution 12: 320325.

Masters, M. J., 1971a. Ecology of Chytridium-deltanum and other fungus parasites on Oocystis spp. Canadian Journal of Botany 49: 75-87.

Masters, M. J., 1971b. Occurrence of chytridium-marylandicum on botryococcus-braunii in school of delta marsh. Canadian Journal of Botany 49: 1479-1485.

Masters, M. J., 1971c. Occurrence of phlyctidium-scenedesmi on pediastrum-boryanum and scenedesmus-quadricauda in school bay of delta marsh. Canadian Journal of Botany 49: 1605-1608.

Masters, M. J., 1976. Freshwater phycomycetes on algae. In Jones E. B. G. (ed), Recent Advances in Aquatic Mycology. Elek Science, London: 489-512.

McQuiod, M. R., A. Godhe \& K. Nordberg, 2002. Viability of phytoplankton resting stages in the sediment of a coastal Swedish Fjord. Europian Journal of Phycology 37: 191-201.

Muehlstein, L. K., J. P. Amon \& D. L. Leffler, 1988. Chemotaxis in the marine fungus Rhizophydiumlittoreum. Applied and Environmental Microbiology 54: 1668-1672.

Müller-Navarra, D. C., M. T. Brett, A. M. Liston \& C. R. Goldman, 2000. A highly unsaturated fatty acid predicts carbon transfer between primary producers and consumers. Nature 403: 74-77.

Müller, U. \& P. Sengbusch, 1983. Visualization of aquatic fungi (Chytridiales) parasitizing on algae by means of induced fluorescence. Archiv fur Hydrobiologie 97: $471-485$.

Murray, A. G., 1995. Phytoplankton exudation-exploitation of the microbial loop as a defense against algal viruses. Journal of Plankton Research 17: 1079-1094.

Noble, R. T. \& J. A. Fuhrman, 1998. Use of SYBR green I for rapid epifluorescence counts of marine viruses and bacteria. Aquatic Microbial Ecology 14: 113-118.

Paterson, R. A., 1960. Infestation of chytridiaceous fungi on phytoplankton in relation to certain environmental-factors. Ecology 41: 416-424.

Pohnert, G., 2000. Wound-activated chemical defence in unicellular planktonic algae. Angewandte Chemie International Edition 39: 4352-4354.

Powell, M. J., 1994. Production and modifications of extracellular structures during development of Chytridiomycetes. Protoplasma 181: 123-141.

Puneva, I., C. Christov \& M. Bozhkova, 2000. The effect of abscisic acid and methyl jasmonate on the hostparasite relationship in the system Scenedesmus acutus Phlyctidium scenedesmi. Russian Journal of Plant Physiology 47: 664-667.

Raghukumar, C., 1986. Fungal parasites of the marine green-algae, Cladophora and Rhizoclonium. Botanica Marina 29: 289-297. 
Raven, J. A., 1998. The twelfth tansley lecture. Small is beautiful: the picophytoplankton. Functional Ecology 12: $503-513$.

Raven, J. A. \& A. M. Waite, 2004. The evolution of silicification in diatoms: inescapable sinking and sinking as escape? New Phytologist 162: 45-61.

Reynolds, C. S., 1973. The seasonal periodicity of planktonic diatoms in a shallow eutrophic lake. Freshwater Biology 3: 89-110.

Reynolds, C. S., 1984. The ecology of freshwater phytoplankton. Cambridge University Press, Cambridge.

Richards, M., 1951. The life history of Diplophlyctis laevis. Transactions of the British Mycological Society 34: 483-488.

Sen, B., 1987a. Fungal parasitism of planktonic algae in Shearwater I. Occurrence of Zygorhizidium affluens Canter on Asterionella formosa Hass. in relation to the seasonal periodicity of the alga. Archiv fur Hydrobiologie/ Suppliment 76: 101-127.

Sen, B., 1987b. Fungal parasitism of planktonic algae in Shearwater II. A study of the chytrid parasites of the diatom Fragilaria crotonensis Kitton. Archiv fur Hydrobiologie/ Suppliment 76: 129-144.

Sen, B., 1988a. Fungal parasitism of planktonic algae in Shearwater. IV. Parasitic occurrence of a new chytrid species on the blue-green alga. Archiv fur Hydrobiologie/Suppliment 79: 177-184.

Sen, B., 1988b. Fungal parasitism of planktonic algae in Shearwater. III. Fungal parasites of centric diatoms. Archiv fur Hydrobiologie/ Suppliment 79: 167-175.

Sen, B., 1988c. Fungal parasitism of planktonic algae in shearwater. V. Fungal parasites of the green algae. Archiv fur Hydrobiologie Suppliment 79: 185-205.

Shin, W., S. M. Boo \& J. E. Longcore, 2001. Entophlyctis apiculata, a chytrid parasite of Chlamydomonas $\mathrm{sp}$ (Chlorophyceae). Canadian Journal of Botany-Revue Canadienne de Botanique 79: 1083-1089.

Smayda, T. J., 1970. The suspension and sinking of phytoplankton in the sea. Annual Review of Oceanography \& Marine Biology 8: 353-414.

Smetacek, V., 1999. Diatoms and the ocean carbon cycle. Protist 150: 25-32.

Sommer, U., 1987. Factors controlling the seasonal variation in phytoplankton species composition-a case study for a deep, nutrient rich lake. Progress in Phycological Research 5: 124-178.

Sommer, U., Z. M. Gliwicz, W. Lampert \& A. Duncan, 1986. The PEG-model of seasonal succession of planktonic events in freshwaters. Archiv fur Hydrobiologie 106: 433-471.

Sparrow, F. K., 1936. A contribution to our knowledge of the aquatic Phycomycetes of Great Britain. Biological Journal of the Linnean Society 50: 417-478.
Sparrow, F. K., 1952. Phytomycetes from the douglas lake region of northern Michigan. Mycologia 44: 759-772.

Stein, J., 1973. Handbook of Phycological Methods. Culture Methods and Growth Measurements. Cambridge University Press, London.

Sterner, R. W., 1989. The role of grazers in phytoplankton succession. In Sommer U. (ed.), Plankton Ecology: Succession in Plankton Communities. SpringerVerlag, Berlin, 107-170.

Strom, S., G. Wolfe, J. Holmes, H. Stecher, C. Shimeneck, S. Lambert \& E. Moreno, 2003. Chemical defense in the microplankton i: Feeding and growth rates of heterotrophic protists on the DMS-producing phytoplankter Emiliania huxleyi. Limnology and Oceanography 48: 217-229.

Suttle, C. A. \& A. M. Chan, 1994. Dynamics and distribution of cyanophages and their effect on marine Synechococcus spp. Applied and Environmental Microbiology 60: 3167-3174.

Taylor, F. J., 1976. Fungal parasite in marine diatom Coscinodiscus-oculus-iridis. Botanica Marina 19: 61-62.

Tehler, A., J. S. Farris, D. L. Lipscomb \& M. Kallersjo, 2000. Phylogenetic analyses of the fungi based on large rDNA data sets. Mycologia 92: 459-474.

Van Donk, E., 1989. The role of fungal parasites in phytoplankton succession. In Sommer U. (ed.), Plankton Ecology: Succession in Plankton Communities. Springer-Verlag, Berlin, 171-194.

Van Donk, E., 2005. Planktonic interactions: developments and perspectives. Verhandlungen der Internationalen Vereinigung für Theoretische und Angewandte Limnologie 29: 61-72.

Van Donk, E. \& K. Bruning, 1992. Ecology of aquatic fungi in and on algae. In Reiser W. (eds.), Algae and Symbioses-Plants, Animals, Fungi, Interactions Explored. Biopress Limited, Bristol, 567-592.

Van Donk, E., M. Lurling \& W. Lampert, 1999. Consumer-induced changes in phytoplankton: inducibility, costs, benefits, the impact on grazers. In Tollrian R. \& C. D. Harvell (eds.), The Ecology and Evolution of Inducible Defenses. Princeton university press, Princeton, 89-103.

Van Donk, E. \& J. Ringelberg, 1983. The effect of fungal parasitism on the succession of diatoms in lake Maarsseveen-I (The Netherlands). Freshwater Biology 13, 241-251.

Webster, J., 1970. Introduction to Fungi. Cambridge University Press, Cambridge.

White, F. F., B. Yang \& L. B. Johnson, 2000. Prospects for understanding a virulence gene function. Current Opinion in Plant Biology 3: 291-298.

Wilson, W. H. \& N. H. Mann, 1997. Lysogenic and lytic viral production in marine microbial communities. Aquatic Microbial Ecology 13: 95-100. 